\title{
ON-LINE QUIZZES TO EVALUATE COMPREHENSION AND INTEGRATION SKILLS
}

\author{
José David Badia Valiente (iD, Françoise Olmo Cazevieille iD, José Manuel Navarro JoveriD \\ GIIMA. Group of Research and Innovation in Active Methodologies, Universitat Politècnica de \\ València (Spain) \\ jdbadia@itm.upv.es, folmo@idm.upv.es, jnavar@dig.upv.es
}

Received October 2015

Accepted January 2016

\begin{abstract}
This work demonstrates the use of a 2.0 tool, namely, Socrative, to evaluate one of the cross-curricular competences indicated by the Universitat Politècnica de València, specifically, comprehension and integration. It has been applied to the courses in different areas: sciences, engineering and languages.

As part of its implementation, activities were proposed that could be done at the beginning, during or at the end of the class to, on the one hand, help students acquire the knowledge associated with the course(s), and on the other, gather evidence that demonstrates acquisition of said competence.

The results show a high level of satisfaction by the students with the use of the Socrative tool as an element to promote active participation and the acquisition of the cross-curricular competence of comprehension and integration; therefore, its extension to other courses has been suggested.
\end{abstract}

Keywords - Comprehension, Integration, Skills, On-line quizzes, Socrative, Active participation.

\section{Introduction}

Within the new context of higher education, it has become essential to promote communication between students and instructors, among students, and among instructors (Olmo \& Navarro, 2014). Increasingly evident is the concern instructors feel and the effort they make to implement teaching methodologies that promote active participation and involvement of students, based on new 
information and communication technologies. Manuguerra and Petocz (2011) indicated the need for evolution in order to approach the teaching-learning process with methodologies that are adapted to the learning styles of the new generations of students. The tools offered by the web 2.0 are ideal for incorporation in this process, as a complement to traditional tools. In the words of Flores (2011), each of these new technology trends offers new hope for education.

Since it was first used in 1999 (DiNucci, 1999), the term web 2.0 has gradually increased in use until today, even in spite of the fact that one of its initial promoters, Tim O'Reilly (2011), declared that the term was already obsolete. It is a concept that encompasses all web sites and applications that facilitate the sharing of information. However, it is not limited to this; in the words of Trujillo and Hinojo (2010), De Haro (2008) and many other authors, users participate actively, they do not simply read, rather they also share, collaborate, discuss, correct, make comments and suggestions, etc. In summary, the suffix 2.0 represents an attempt to identify any process where the main activity is the free interaction of people (Fernández, 2006).

Along the lines of the approach by Harris and Hofer (2009), which describes the three basic pillars of instructional planning (knowledge of the discipline, pedagogy and technology), this work is situated at the junction between pedagogical and technological aspects.

In this teaching-learning process, this study focuses on the framework of new degrees and the European Convergence process, specifically, on competence-based education. The Universitat Politècnica de València has drafted a list of generic competences that are to be verified and evaluated during the current academic year, as a starting point for accreditation of the degrees by the quality agencies.

León, Peñalba and Escudero (2002) conducted a thorough study on the importance of generating questions in the educational environment, based on Hyman (1979); they proposed a classification of the types of questions that are generally asked, adapted from Graesser, Person and Huber (1993), and subsequently made a series of suggestions and recommendations in this regard. On the one hand, the asking of questions in the classroom by instructors stimulates students' thinking and learning-building processes; on the other hand, it may prove to be very useful as an instrument to measure comprehension (Navarro \& Olmo, 2014).

The use of poll-type technologies to create in-class questionnaires and thus obtain immediate feedback has gradually expanded in recent years. Sun (2014) observed that the use of questionnaires via mobile devices increased the amount of attention students paid, and improved 
their academic results. Likewise, a better result was obtained by using smartphones to record responses as compared to clickers, in the sense that the former were less distracting, since the students were already familiar with them.

There are numerous poll-type web 2.0 applications that enable questionnaires to be created to gather immediate information through on-line electronic devices. Most are very simple to manage and to use to create questions, and they have very attractive interfaces (e.g. Polleverywhere.com, Easypolls.net, PollDaddy, MicroPoll.com, etc.). Some do not even require registration, which is fast and convenient for occasional use, but they do not allow you to save the questions, tests or responses.

In the work by Navarro and Olmo (2014), the Socrative application was used to promote student participation in face-to-face classes. The present study attempts to adapt it as an instrument to evaluate the generic competence of comprehension and integration, in order to, in the words of the Universitat Politècnica de València, "demonstrate the comprehension and integration of knowledge, both of the specialization itself and in other broader contexts," so that students "are capable of engaging in basic processing of the contents, thinking actively about the subject, comparing concepts, principles and theories, organizing them according to common characteristics, analyzing factors that influence them and synthesizing results and conclusions, among other cognitive activities." Socrative is very simple to use, with a wide variety of types of questions and surveys, and it is possible to generate and save reports with the information collected, even in the free version. For these reasons, and because none of the tools mentioned above provides any significant new features for the purposes of this work, the decision was made to continue using Socrative.

The aim of this work is to establish tools to support the evaluation of the cross-curricular competence of comprehension and integration, based on systems of on-line questionnaires used in the classroom, which make it possible to collect evidence, foster participation and encourage active learning on the part of the students. 


\section{Methodology}

This study used the 2.0 questionnaire application Socrative to ask students questions at different moments of the on-site class, with different focuses depending on the exact moment, i.e. at the beginning (PRE), during (DUR) or at the end (POST) of the class session. This study was conducted during one teaching unit of each course.

The Socrative software is an application that enables instructors to ask questions about the topic being studied in class, or about necessary prerequisite knowledge, either orally or through predesigned questionnaires, individually or in groups, anonymously or identifying the respondents, as required; the instructor collects the results instantaneously and can analyze them, comment on them and/or save them for later.

In order to facilitate communication between students and the instructor during the class, and in order to answer the questions asked by the latter, both sides must be running the Socrative tool. It can be launched:

- from the web browser (Socrative.com), if computers are available in class, with no software installation required.

- from a mobile device, using the previously downloaded application (for Android or iPhone) or the device's web browser. This enables it to be used during classroom lectures, where computers are not available and there are generally a large number of students.

The instructor creates an account (teacher login) that is linked to a virtual room with an identification number. The students access the system through the student login (see Figure 1) and enter the room number provided by the instructor. From this moment on, they receive the questions or quizzes launched directly from the instructor. 


\section{Figs socrative}

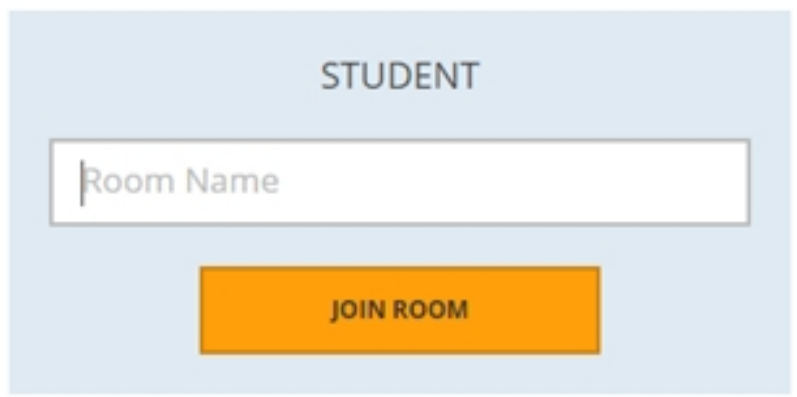

Figure 1. Student access to the Socrative room

The instructor, in turn, can suggest two types of activities using the Socrative tool: those based on questionnaires or quizzes and individual questions (see Figure 2).

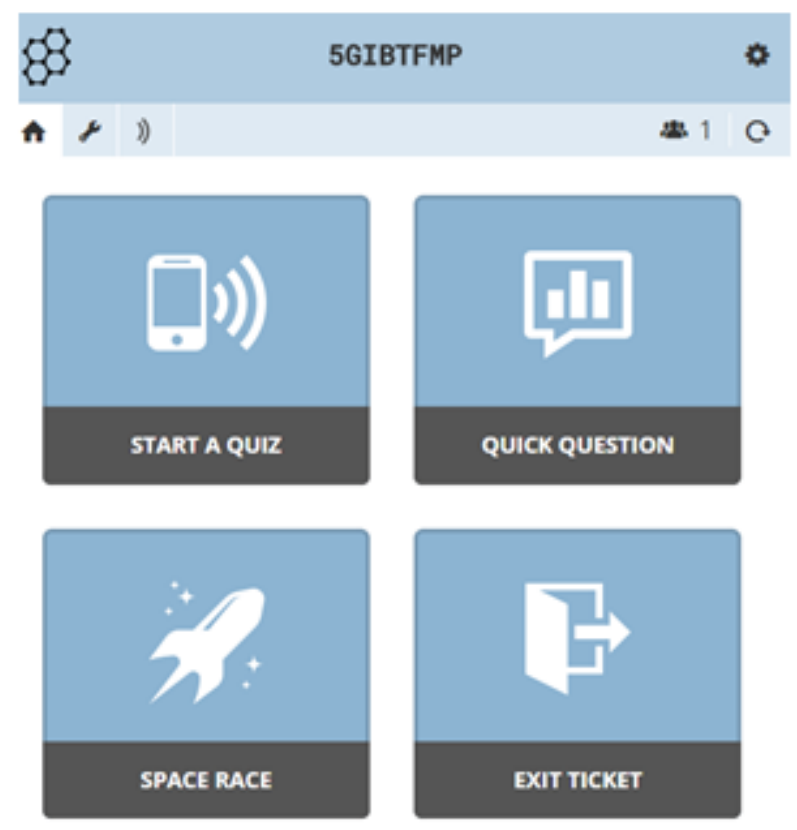

Figure 2. Room as seen by the instructor 
The quizzes or questionnaires are written before class and there is an option to share them with other instructors or rooms.

Individual questions (quick questions) can be:

- Multiple choice: With as many as 5 options (A, B, C, D, E); the instructor asks the question and gives the answer options out loud in the classroom, and the students answer by selecting one of the options.

- True/False: Just like above, but with only these two answer options.

- Short answer: Students must answer by writing their responses. Each student can submit one or more responses (as selected). This type of question also allows the results to be displayed afterwards (on a projector) for a class vote in which the students select what they believe to be the correct or most appropriate answer from all the answers submitted by the class.

As an example, the questionnaire used to evaluate the methodology of this work has been made available in room 5GIBTFMP of Socrative, which may be accessed as a student.

Figure 3 shows the student-teacher relationship behind the methodology used in this study, by means of the completion of PRE, DUR and POST questionnaires. The following advantages can be highlighted:

- Feedback: Students may obtain immediate information in situ about their level of preparation to address the new contents, enabling them to quickly modify and adapt the time and effort they dedicate to the subject.

- Evaluation-based evidence: Instructors collect information about any differences that might exist between the expected level and that actually reached, thus enabling them to adapt the current session (in PRE-type activities, it enables them to develop a prior outline that organizes the theoretical concepts seen in a previous session in order to address problems that might arise in the current session) or a future session (in POSTtype activities, to reinforce any weak areas or inconsistencies that are detected).

- Connection: The use of 2.0 technologies bridges the gap between the language used by instructors and that used by students, thus encouraging greater participation, which results in closer attention and culminates in more effective learning. 


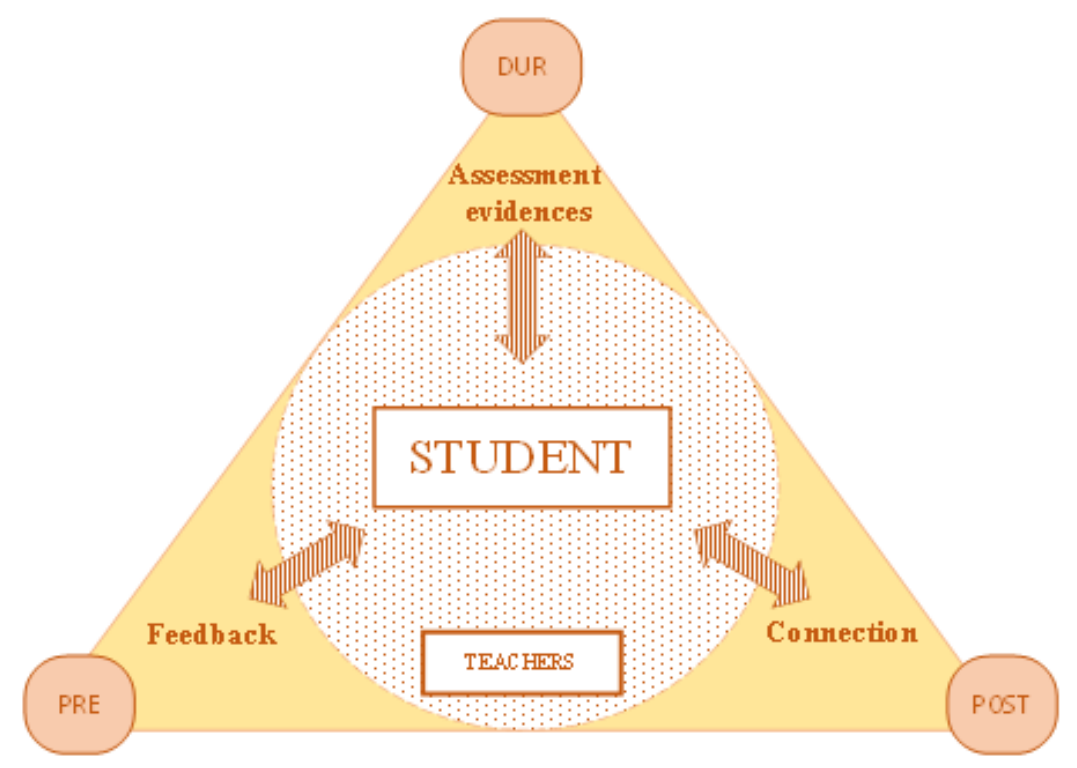

Figure 3. The student-instructor relationship behind the activities to evaluate the competence comprehension and integration

\subsection{Activities}

The tool was tested in two different courses at the Higher Technical School of Agricultural and Environmental Engineering (ETSIAMN) at the Universitat Politècnica de València and in one course at the Higher Technical School of Engineering (ETSE) at the Universitat de València during the 2014/2015 academic year. The activities designed and developed in each are described separately below, even though the results are later analyzed altogether.

\subsubsection{PRE-type activity}

Course: Materials Science II, 6 ECTS, a second-year core course in the Chemical Engineering degree program. 45 students.

During the problem sessions, questionnaires were completed that had been prepared specifically to evaluate whether the students have acquired, understood and associated the most important concepts and procedures from the classroom lectures in order to then tackle the problems. All questions asked in this course were multiple choice, which students answered using mobile phones and other portable electronic devices, with an overall time of 10 minutes spent on the activity. 


\subsubsection{DUR-type activity}

Course: Graphic Representation in Engineering, 6 ECTS, a first-year core course in the Agrifood and Rural Environment Engineering degree program. 43 students.

During the classroom lectures, a series of quick questions were asked in order to obtain feedback on the level of comprehension of the most important concepts being studied. There are three types of quick questions used: true/false, multiple choice (see an example in Figure 4) and short answer involving simple numeric calculations. The questions are presented orally or in written form by the instructor, but they are not shown in Socrative. This type of question is intended to be asked and answered in class, unlike the quizzes, which can be left open for as long as desired.

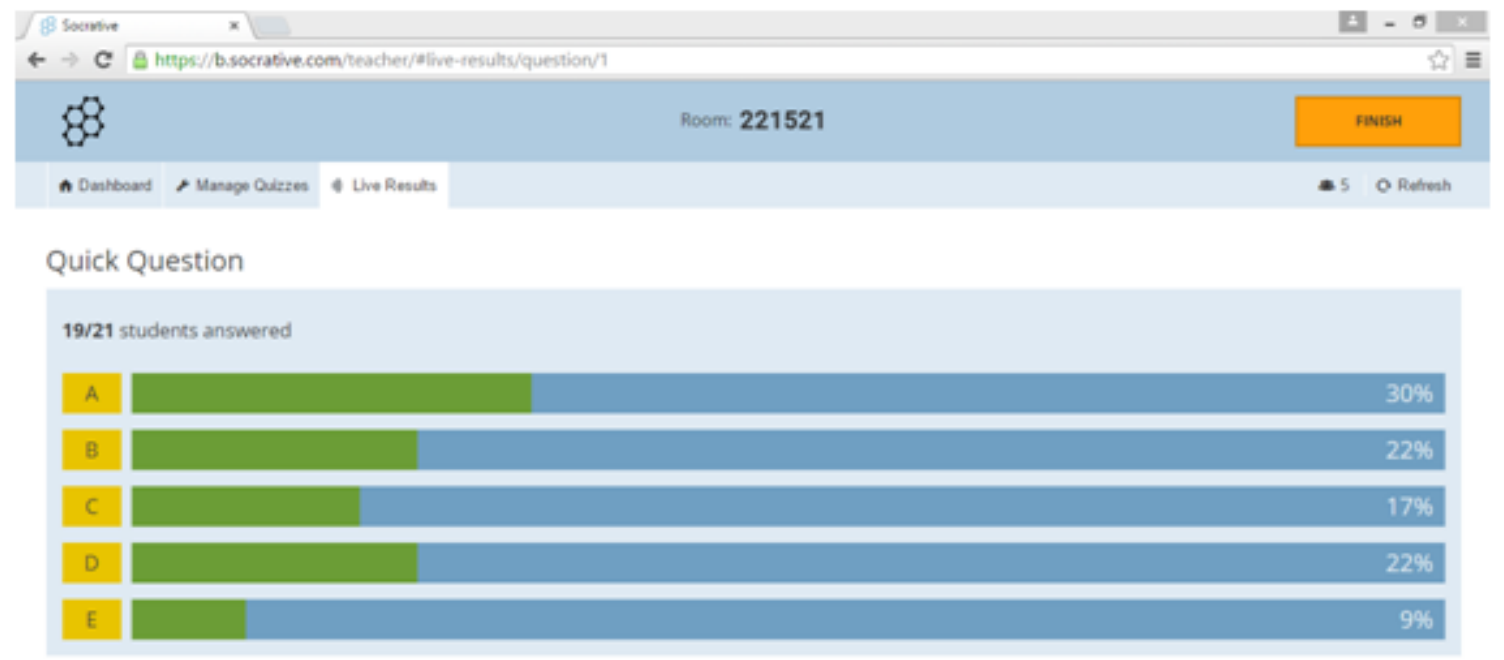

Figure 4. Results of the answers to a multiple choice quick question

\subsubsection{POST-type activity}

Course: French for Biotechnology, 6 ECTS, a second-year elective course in the Biotechnology degree program. 15 students.

In this course, the activities involving the use of Socrative at the end of a topic consisted of two questionnaires that were written to check whether the grammar points covered during the class had been understood and retained, and to review the most difficult aspects. The first concerned question formation and consisted of 11 short answer questions, while the second focused on imperative statements and included 2 multiple choice and 7 short answer questions. 
At the start of the session in the virtual room, the first question on the quizzes always asks for the student's name. It is up to the instructor to decide whether they want to use this option. In this post-type activity, each student was identified in order to allow the instructor to monitor them. That way, upon consulting the output report, the instructor could see where each student made mistakes and follow their progress on a more individual level, retrieving this document as evidence for evaluation. Figure 5 shows an example of an output report in Excel file format, generated by the application.

\begin{tabular}{|c|c|c|c|c|}
\hline \multirow{2}{*}{\multicolumn{5}{|c|}{ L'interrogation }} \\
\hline & & & & \\
\hline \multicolumn{5}{|c|}{ Thu, May 22 04:11 AM } \\
\hline \multicolumn{5}{|c|}{ Room: 181934 (folmo@idm.upv.es) } \\
\hline $\begin{array}{l}\text { Please enter last } \\
\text { name, first name } \\
\text { (ex. West, } \\
\text { Michael): }\end{array}$ & $\begin{array}{l}\text { Transformez cette phrase } \\
\text { en interrogation avec "est- } \\
\text { ce que": Tu viens quand? }\end{array}$ & $\begin{array}{l}\text { Transformez cette } \\
\text { phrase en utilisant } \\
\text { Finversion du sujet: Tu } \\
\text { vas nous quitter? }\end{array}$ & $\begin{array}{l}\text { Transformez avec Tinversion } \\
\text { su sujet: Pierre habite en } \\
\text { France }\end{array}$ & $\begin{array}{l}\text { Transformez avec } \\
\text { Pinversion du sujet: } \\
\text { Sylvie habite où? }\end{array}$ \\
\hline Lens & quand est-ce que tu viens? & vas-tu nous quitter? & Pierre habite-t-il en France & Sylvie habite-t-elle où? \\
\hline Evin: & est-ce que tu viens? & vas-tu nous quitter? & Pierre habite-t-il en Frane & Sylvie oủ habite-t-elle? \\
\hline Nos & Quand est-ce que tu viens? & Vas-tu nous quitter? & Pierre habite-t-il en France? & Oủ Sylvie habite-t-elle? \\
\hline croves & Quand est-ce que tu viens? & Vas-tu nous quitter? & Pierre habite-t-il en France? & Où Sylvie habite-t-elle? \\
\hline Mexis & est-ce que tu viens quand? & Vas-tu nous quitter? & Pierre habite-t-il en France? & Sylvie où habite-t-elle? \\
\hline reanses & Quand est-ce que tu viens? & vas tu nous quitter? & Pierre habite-t-il en France? & Sylvie habite-t-elle oủ? \\
\hline Ma & Este-ce que quan tu viens? & Vas tu nous quitter? & & Sylvie habite-t-il où? \\
\hline Comm & Quand est-ce que viens? & Je ne respond pas & Pierre habite il en France? & Ou habite-t-il Sylvie? \\
\hline entort & viens-tu quand & vas-tu desertor nous & Pierre, habite-t-il en France? & Habite-t-elle oú? \\
\hline Fith & Quand est-ce que tu viens? & Vas-tu nous quitter? & Pierre habite-t-il en France? & sylvie où habite-t-elle? \\
\hline
\end{tabular}

Figure 5. Example of an output report generated by Socrative

\subsection{Opinion survey}

To evaluate the methodology applied, the students were given a survey, also using the Socrative questionnaire technology, asking them on the one hand, about how friendly the technology is, and on the other, about the effect it has on the student's instruction. The questions were asked specifically to make the students aware of the value of cross-curricular competences, in general, and what is expected of them in terms of the comprehension and integration competence, in particular. 


\section{Results and discussion}

\subsection{Accessibility of the tool and active participation}

The overall results obtained in the three courses (Figure 6) demonstrate that in a computer classroom, most of the students accessed the tool from a computer, while in a classroom without computers, they primarily accessed it from a mobile telephone $(65 \%)$ or a tablet $(22 \%)$. In the case of access from a mobile phone or tablet, more than half the students (54\%) did so through the web, without installing the application.
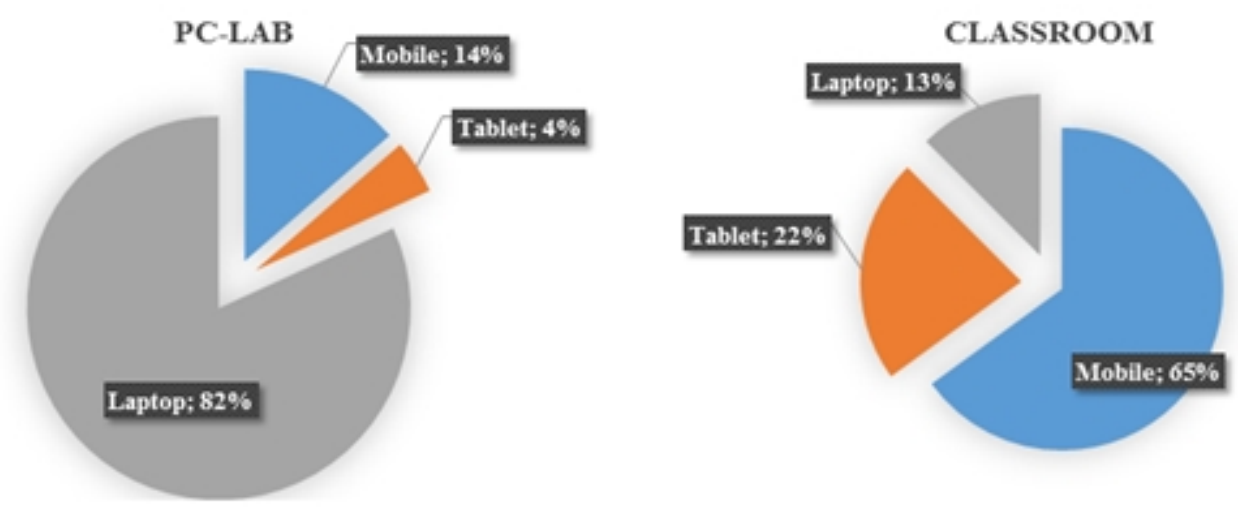

ACCESS IN CASE OF MOBILE OR TABLET

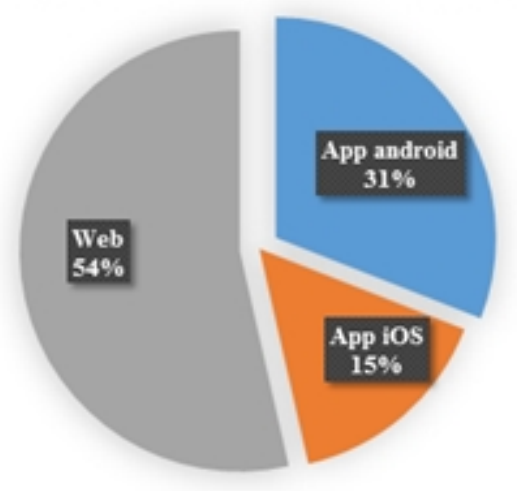

Figure 6. Results of the survey on accessibility: use in classroom with and without computers and type of access when using a mobile phone or tablet 
Figure 7 shows a radar chart of the results (number of responses as an absolute value out of a total of 84 students) for the four questions regarding ease of use and the contribution made by the tool to participation, involvement and self-assessment of the students. Of the respondents, $88 \%$ agree or totally agree that the tool is easy to use. Only $6 \%$ express having difficulties. $82 \%$ consider that the methodology promoted participation in the course. Along the same lines, $85 \%$ feel that the tool is interesting, because it gets them involved throughout the entire activity, while only $4 \%$ disagree with this statement. Finally, it is noteworthy that a large part of the students $(88 \%)$ believe that the application is also useful for self-assessment.

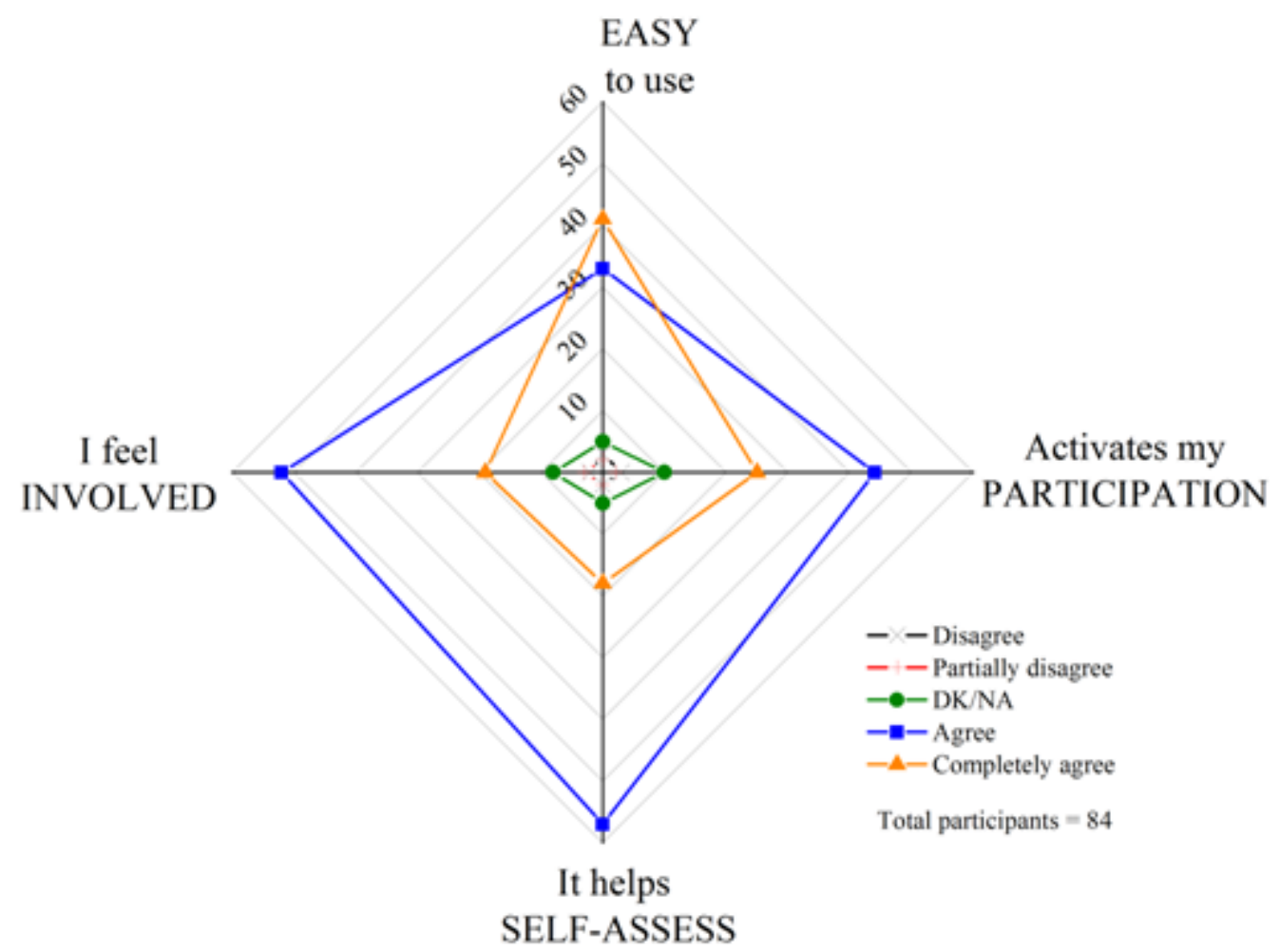

Figure 7. Results of the survey on active participation

\subsection{Comprehension and integration competence}

Figure 8 presents the results on the perception of the incidence of the application on the comprehension of specific knowledge in each course and its contribution to the integration of prior knowledge with that which is being acquired. Most of the students, $86 \%$, indicate that it helps them understand better, while only $7 \%$ disagree. As far as integration is concerned, the 
result is similar to that above; $81 \%$ indicate that it contributes to integrating new knowledge. Finally, 85\% would recommend the use of the tool in other courses (see Figure 9).

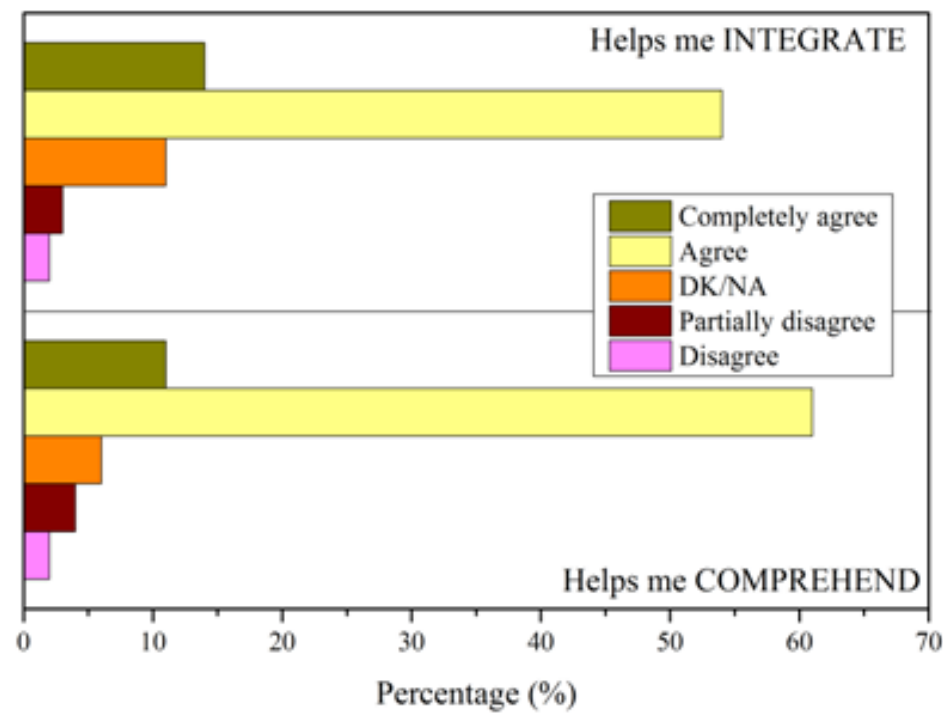

Figure 8. Results of the survey on the comprehension and integration competence

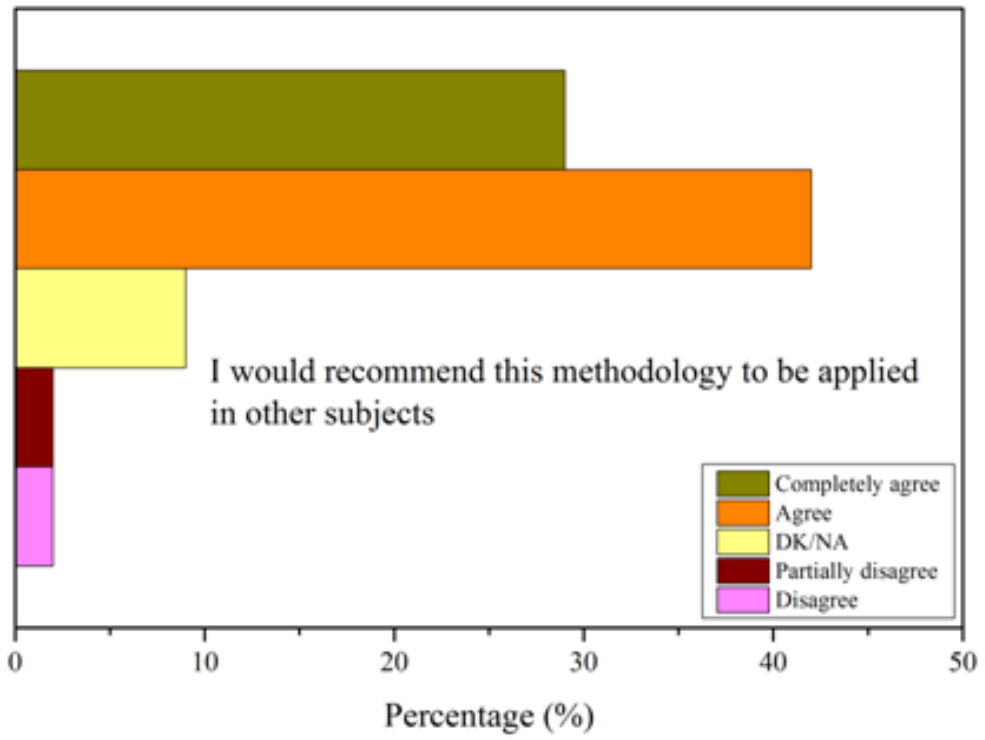

Figure 9. Responses to the question "Would you recommend the use of this tool in other courses?" 
With regard to the comments and suggestions, the students tended to view the questions asked positively. Some of the comments are shown below.

- "It is a good tool to review what we have learned so far."

- "Good to apply knowledge in an interactive, and therefore, entertaining manner."

- "The on-line experience improves from a mobile phone."

- "I like this tool a lot; it makes you participate actively in the class."

- "Interesting for learning more and on top of that, it is more fun."

- "Good application to clarify prior knowledge."

- "It could be used more often."

It can be concluded from these comments that during the activity, the students feel in demand, as they must answer all the questions, improve their comprehension, because they receive direct feedback from the instructor, who focuses explanations on the mistakes made, and integrate the new knowledge with that which has already been acquired.

Through the tool, the instructor collects evidence of comprehension and integration of the knowledge specific to his or her course, as the reports issued provide proof that the learner has been capable of carrying out an integrated processing of the contents and of thinking actively about the material.

The few drawbacks to this methodology are related to the difficulties encountered by some people when connecting via the web.

\section{Conclusions}

This work shows the virtues of the Socrative tool for boosting the development of the crosscurricular competence of comprehension and integration through activities that are completed in the classroom, before, during and after the explanatory session.

Students appreciated the easy technological access to the Socrative tool, regardless of the device being used (computer, tablet or mobile phone) or the software serving as the interface (web, iOS or Android). 
The use of Socrative promotes active participation and the involvement of students in the course, and at the same time, it is perceived as a suitable tool for self-assessment.

Most students believe that the use of Socrative is positive and useful for acquiring the competence of comprehension and integration, demonstrating a high level of satisfaction, which suggests that its use be extended to other courses.

The results obtained support what Trujillo and Hinojo (2010), among other authors, have observed: the tool contributes to active participation on the part of the students. They are also in agreement with Navarro and Olmo (2014), who claim that it stimulates learning processes and is very useful for measuring comprehension. Without a doubt, this study has demonstrated that Socrative is also a valid tool for developing the competence of comprehension and integration, and for gathering evidence of this.

It is now required, on the one hand, to carry out further research in order to determine whether this application can be of assistance for the acquisition of other cross-curricular competences, and on the other hand, to continue to keep pace with the progress made on 2.0 tools, in order to adapt them to teaching practices.

\section{Acknowledgements}

The authors thank the aid of Universitat Politècnica de València by means of the project of innovation in educative methodologies PIME 2015-A020 "Análisis de la implementación y evaluación de competencias transversales en los primeros cursos de ingeniería" (Analysis of the implementation and assessment of cross-curricular competences at the first courses of engineering"

\section{References}

De Haro, J.J. (2008, Enero 4). Aplicaciones 2.0. EDUCATIVA, Available online at: http://jideharo.blogspot.com.es

DiNucci, D. (1999). Fragmented future. Cengage Learning, Inc., 53(4), 32.

O’Reilly, T. (2011), Economías y ecosistemas de contenidos, V Foro Internacional de Contenidos Digitales, 22-24/11/2011, Madrid, spain 
Fernández, E. (2006). Web 2.0: Sindicación de contenidos [RSS]. Didáctica, Innovación y Multimedia, 8. Available online at: http://dim.pangea.org/revista8.htm

Flores, M. (2011). Recursos de la Web 2.0 en la Educación. Revista Electrónica de Investigación Educativa, 13(1). Disponible online at: http://redie.uabc.mx/vol13no1/contenido-floresvalentin.html

Graesser, A.C., Person, N.K., \& Huber, J. (1993). Question asking during tutoring and in the design of educational software. In M. Rabinowitz (Ed.), Cognitive science foundations of instruction (pp. 149-172). Hillsdale, NJ: Erlbaum.

Harris, J., \& Hofer, M. (2009). Instructional planning activity types as vehicles for curriculumbased TPACK development. In C. D. Maddux, (ed.). Research highlights in technology and teacher education (pp. 99-108). Chesapeake, VA: Society for Information Technology in Teacher Education (SITE).

Hyman, R.T. (1979). Strategic questioning. Englewood Cliffs, N.J.: Prentice-Hall.

León, J.A., Peñalba, G., \& Escudero, I. (2002). Profe, ¿puedo preguntar? Una breve introducción a la interacción de preguntas y respuestas entre profesor y alumno. Psicología Educativa, 8(2), 107-126.

Manuguerra, M., \& Petocz, P. (2011). Promoting Student Engagement by integrating New Technology into Tertiary Education: The Role of the iPad. Asian Social Science, 7(11), 61-65. http://dx.doi.org/10.5539/ass.v7n11p61

Navarro, J.M., \& Olmo, F. (2014). Socrative, una aplicación web 2.0 para evaluar la comprensión de los estudiantes. In V. Botti, M.A. Fernández, J. Simó \& F. Fargueta (eds.), Jornadas de Innovación Educativa y Docencia en Red de la Universitat Politécnica de València. (pp. 69-79). Valencia: Editorial Universitat Politécnica de València.

Olmo, F., \& Navarro, J.M. (2014). La tutoría virtual en la enseñanza universitaria. La individualización de la formación. Revista del CIDUI, 2. Available online at: http://www.cidui.org/revistacidui/index.php/cidui/article/view/605

Sun, J.C.-Y. (2014). Influence of polling technologies on student engagement: An analysis of student motivation, academic performance, and brainwave data. Computers \& education, 72, 80-89. Available online at: http://www.cidui.org/revistacidui/index.php/cidui/article/view/605 http://dx.doi.org/10.1016/i.compedu.2013.10.010 
Trujillo, J.M, \& Hinojo, F.J. (2010). Apropiación de recursos y estrategias 2.0 para la innovación educativa en la docencia universitaria. Enseñanza \& Teaching, 28, 61-77.

Published by OmniaScience (www.omniascience.com)

Journal of Technology and Science Education, 2016 (www.jotse.org)

\section{(a)}

Article's contents are provided on an Attribution-Non Commercial 3.0 Creative commons license. Readers are allowed to copy, distribute and communicate article's contents, provided the author's and JOTSE journal's names are included. It must not be used for commercial purposes. To see the complete licence contents, please visit http://creativecommons.org/licenses/by-nc/3.0/es/ 